\title{
CHARTS
}

\section{InClusions in NATURAL, SYNTHETic, AND TREATED DIAMOND}

Nathan D. Renfro, John I. Koivula, Jonathan Muyal, Shane F. McClure, Kevin Schumacher, and James E. Shigley

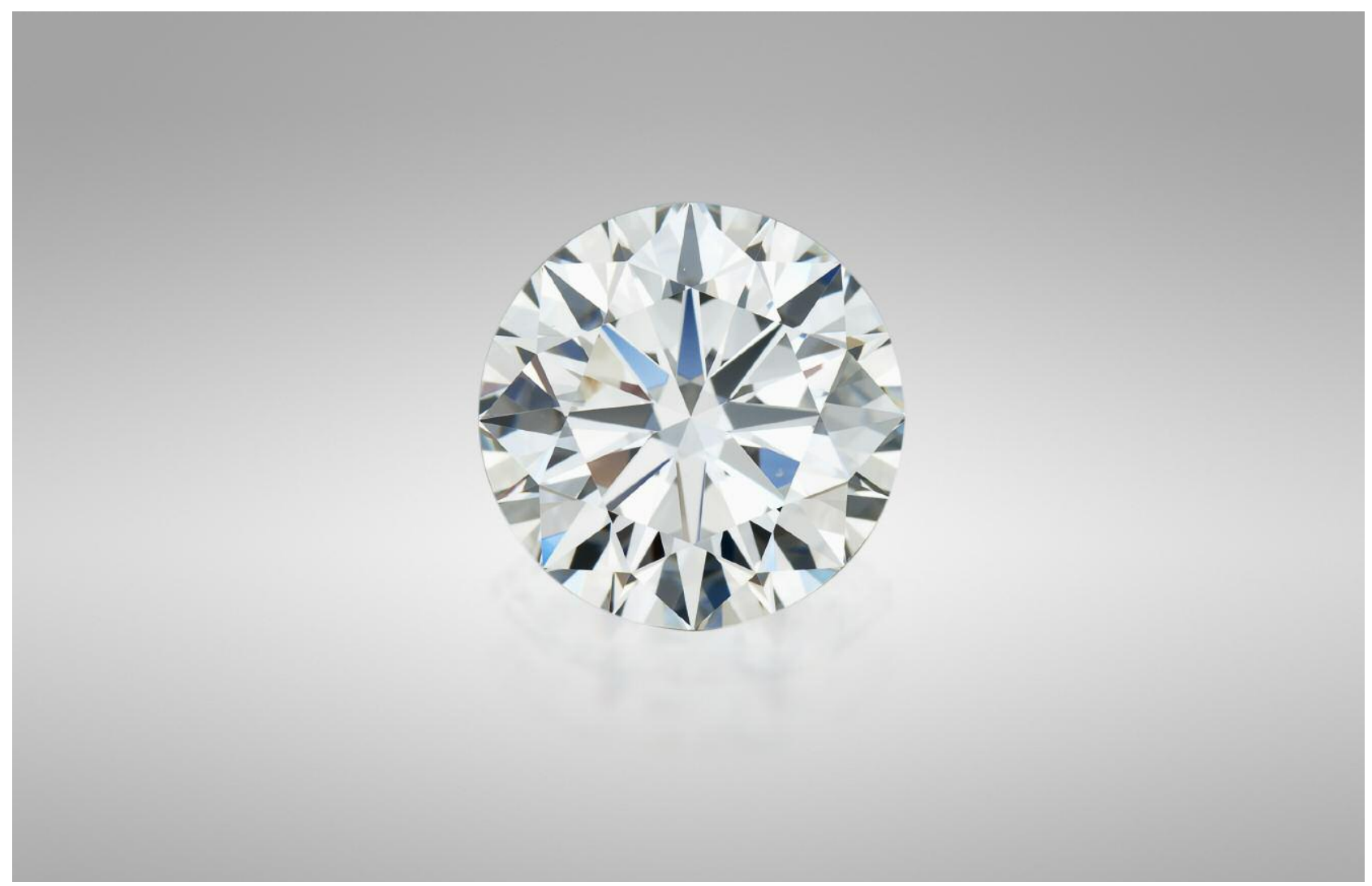

Figure 1. Diamonds such as this $1.15 \mathrm{ct}$ round brilliant are some of the most highly sought-after gem materials and may contain inclusions that give the gemologist clues about their origin or treatment status. Photo by Robert Weldon.

$\mathrm{D}$ iamonds (figure 1) are the subject of the latest chart in our series on the micro-features of gemstones. One of the most highly-sought gem materials, diamond-like emerald, sapphire, and ruby-may be treated or grown in laboratory conditions. While many diamonds contain inclusions that are indicative of their origin or treatment status,

See end of article for About the Authors.

Gems \& Gemologr, Vol. 54, No. 4, pp. 428-429,

http://dx.doi.org/10.5741/GEMS.54.4.428

(C) 2018 Gemological Institute of America many gem-quality diamonds are free of such diagnostic characteristics and will require advanced gemological testing to determine whether they are mined, laboratory grown, or treated. For example, chromian garnet inclusions can indicate the diamond formed in a peridotitic environment, while omphacite and kyanite would suggest an eclogitic environment. Other features that are notably diagnostic to the gemologist are so-called "flash-effect" colors that decorate lead glass-filled fractures and tapering tubes that indicate laser drilling.

Gem-quality synthetic diamonds have been commercially available since 1986; however, recent im- 
provements in growth methods are responsible for increases in both the size of finished stones and the quantity produced. Chemical vapor deposition (CVD) and high-pressure, high-temperature (HPHT) processes have had increasing impact in the diamond trade, with CVD stones reaching finished sizes of more than five carats (Eaton-Magaña and Shigley, 2016) and a $15 \mathrm{ct}$ HPHT-grown specimen recently reported (Ardon and Eaton-Magaña, 2018). Melee-size material is also becoming widely available. As a result, GIA offers a melee screening service and has developed a consumer diamond screening device, the iD100, to separate natural and synthetic specimens.
Treatments intended to improve a diamond's clarity have been around since the late 1970s and include laser drilling and the filling of cracks with a lead glass; this glass reduces the impact of a crack's appearance on the stone (Koivula et al., 1989). Other treatments may improve or modify the bodycolor of a diamond. Irradiation and HPHT treatment can accomplish this but often leave no microscopic evidence of the process.

While the accompanying chart is not meant to be comprehensive, it aims to remind the gemologist of the microscopic evidence that one may encounter and what that evidence indicates regarding a diamond's natural, treated, or synthetic origin.
ABOUT THE AUTHORS

Mr. Renfro is manager of colored stones identification, and John Koivula is analytical microscopist at GIA in Carlsbad, California. Mr. Muyal is a staff gemologist, Mr. McClure is global director of colored stone services, Mr. Schumacher is a photo and video producer for Gems \& Gemology, and Dr. Shigley is distinguished research fellow at GIA in Carlsbad.

\section{REFERENCES}

Ardon T., Eaton-Magaña S. (2018) Lab Notes: 15 carat HPHT synthetic diamond. $G \uplus G$, Vol. 54, No. 2, pp. 217-218.

Eaton-Magaña S., Shigley J.E. (2016) Observations on CVD-grown synthetic diamonds: A review. $G \uplus G$, Vol. 52, No. 3, pp. 222 245, http://dx.doi.org/10.5741/GEMS.52.3.222
Koivula J.I., Kammerling R.C., Fritsch E., Fryer C.W., Hargett D., Kane R.E. (1989) The characteristics and identification of filled diamonds. GÆG, Vol. 25, No. 2, pp. 68-83, http://dx.doi.org/ 10.5741/GEMS.25.2.68

\section{Additional Reading}

For a list of references pertaining to inclusions in natural, synthetic, and treated diamond, go to www.gia.edu/gems-gemology/winter-2018-suggestedreading-diamond-chart or scan the QR code on the right.
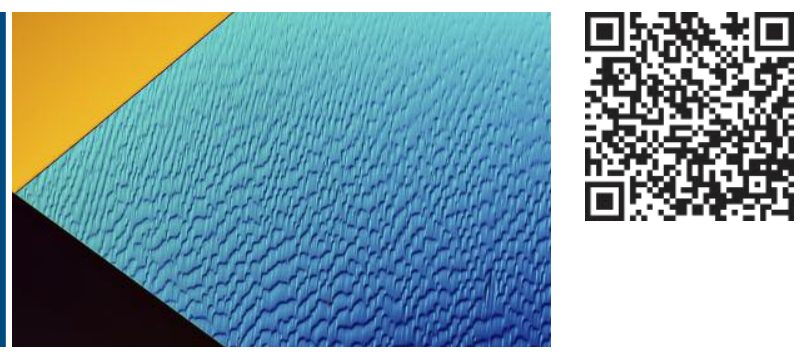